\title{
1. Business creation: Wall Street and Main Street
}

On October 28, 2003 Harvard students could use "Facemash" to compare which photos of two undergraduates was "hot" or "not hot." Developed as personal project by Mark Zuckerberg it was followed by several other efforts that led to the implementation of "Thefacebook" on February 4, 2004; this provided students a mechanism for internet-based social interaction. A five-person start-up team embellished the potential for interaction and expanded access to other universities, high schools and eventually anybody over 13 years old. When the first public offering was initiated in 2012, "Facebook" reported annual revenue of $\$ 5$ billion, yearly profits of $\$ 53$ million, one billion users, and 4,619 employees.]

The McDonald brothers opened their first self-service (no carhops) food stand in San Bernardino, California in 1948, designed to provide fresh hamburgers at half the price of the competition. By 1954 they had five additional franchises and attracted the attention of a milk shake machine salesman, Ray Kroc. He secured the rights to expand franchises outside the southwest and began to implement restaurants in the upper Midwest. With rapid expansion of a new franchise model, Kroc bought out the McDonald brothers in 1961 and by 1968 had 1,000 units. Worldwide the 38,000 restaurants had $\$ 96$ billion in sales in 2018.

Uber provides, by connecting client and driver smartphones, a service to link passengers with those using their personal cars to provide transportation. While the business was initiated in 2009, several versions were developed leading to UberX, which provided direct competition with taxis in 2012. The minimal qualifications required to be an Uber driver and the rigidity of licensed taxi services in major cities lead to dramatic expansion and by 2018 as many as 400,000 were listed as Uber self-employed drivers, compared to 200,000 employed as taxi drivers and chauffeurs. The Uber system appears to increase the productivity of providing transportation and has reduced both the cost to consumers and the earnings of traditional taxi drivers and chauffeurs. Since 2010 Uber has raised $\$ 22$ billion in 18 rounds of financing from venture capital and private equity investors. By 2018 Uber had 12,000 employees and losses continued at several billions a year.

These examples all represent businesses with spectacular growth. Facebook has been at the forefront of creating an entirely new sector of activity-social media. McDonalds is one of several chains having a major impact on an existing sector, restaurants, by dramatically altering the underlying processes involved in sourcing materials and delivering food to customers. Uber represents an intermediate case, while it competes with existing public and 
commercial transportation, it appears to have expanded the sector by providing different forms of service, often in different communities.

Most would consider these as examples of "real entrepreneurship," reflecting high growth and providing something new or different. The potential impact on existing businesses is often considered "creative destruction.' Referring to the effect of business creation on the destruction, or adjustment, of existing business practices. Once they become substantial enterprises, such businesses receive a great deal of attention and those interested in economic growth seek to replicate their success.

While there are many examples of market creation or Wall Street entrepreneurship, they are rare and unique initiatives. Combined with the lack of consensus on what constitutes entrepreneurship, it is difficult to even count initiatives with the potential for a dramatic impact. Trying to identify them when they are informal start-ups is virtually impossible.

\section{BUSINESS CREATION}

In 2003 a team of three men and one woman began developing "Southeast Foundations Are Us," which would prepare building sites for new construction. They anticipated a firm that would be easy to manage and have 25 employees in five years. Within two and a half years they became profitable; two years later they had sales of $\$ 2.4$ million and 10 full time employees.

Maria and Jose, American born Hispanics, were in their mid-thirties and both had two decades of experience in the auto repair business. They considered this a market with growing demand and bilingual service a competitive advantage. As equal partners, they planned to develop a growth business that would provide independence, flexibility to care for their children and better security than their previous jobs. They began slowly, initially securing supplier credit. After four months, they had their first paying customer and after six months were developing a business model, defining the customer base, procuring supplies, acquiring capital assets, investing personal funds, and organizing the business. In the second year of the start-up process they hired employees, developed a business plan and promoted the business. Monthly profitability occurred 16 months after starting the process. 10

These examples, reflecting hundreds of thousands of nascent ventures implemented annually in the United States, are more modest initiatives. In both cases teams with prior experience in a market sector identified a business opportunity and took steps to implement a new venture. Both new firms would affect an existing market, by providing price competition and perhaps new ways of providing an established product—building foundations and auto repair.

Individually, these small-scale Main Street efforts do not attract much attention, there is a tendency to dismiss them as insignificant - as mice among elephants. But while the impact of Southeast Foundations are Us and the Hispanic auto repair may be modest, they represent hundreds of thousands of new firms 
implemented every year-a lot of mice can weigh as much as an elephant. The aggregate contributions of these modest ventures are as significant as those of the major players and provide continuous adjustments to the economy. These gradual adaptations help to mitigate the social cost associated with churning among the business population.

\section{BUSINESS CREATION AND THE ECONOMY}

Business creation, the core feature of entrepreneurship, is associated with economic growth and adaptation. Given the substantial benefits, business creation is an appropriate focus for policy makers. But it is challenging to identify policies that will facilitate responsible entrepreneurship that contributes to the common good. A more comprehensive understanding of business creation can lead to more effective and efficient programs.

There are two ways to consider the contributions of firm creation to economic growth. The simplest model, represented in Figure 1.1, emphasizes a direct relationship to economic growth. Much of the emphasis by entrepreneurial advocates reflect a unilateral relationship - more firm creation leads to more good things.

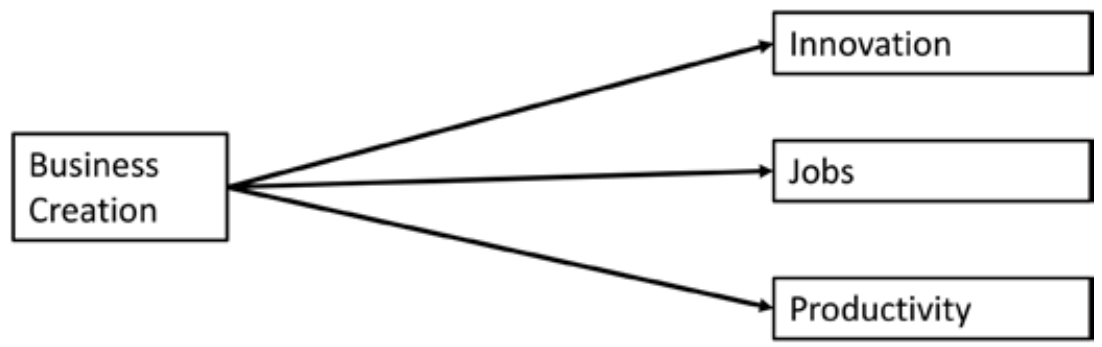

Figure 1.1 Direct effects of business creation

A more comprehensive model may be more useful in developing effective public policies. The conceptualization represented in Figure 1.2 presents business creation as an intermediate (or mediating) factor linking aspects of the context with economic improvements. Furthermore, it includes contributions by established firms, reflecting an awareness that both new and existing businesses make contributions to innovation, job growth and improved productivity.

This more comprehensive model assumes that the potential for business creation is a critical intermediate process between the context and economic growth; necessary but not sufficient. 


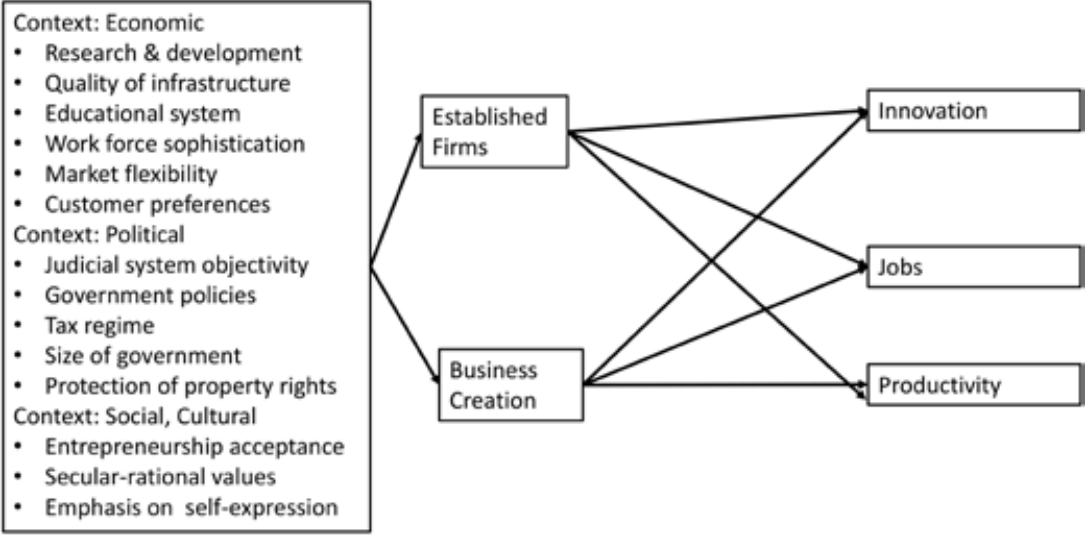

Figure 1.2 Business creation in context

\section{THINGS TO KNOW}

Public policies are most effective when they have wide acceptance by diverse constituencies. Developing political support is easier when empirical patterns are summarized in straightforward, direct statements. The emergence of new firms and contributions to the economy can be considered at two levels.

The broader issues link the general features of the context and business population dynamics with the beneficial outcomes, such as innovation, jobs, and market expansion. They are represented in the top rows of Table 1.1. One of the more critical issues is that the contributions of business creation may vary for nations, or regions, in different stages of economic development. There is, for example, evidence that different people pursue business creation in advanced compared to low income economies.

Businesses are, however, created by people - individually and in teamsand a second set of issues are related to the details of the business creation process. These are represented in the second set of rows of Table 1.1. Not all features of the business creation process have a strong policy relevance, those chosen for attention are the most significant. The following chapters will review these issues in more detail. The final chapter is a commentary on the potential impact of policy adjustments. 


\title{
Table 1.1 Business creation issues for policy makers
}

\author{
The big picture \\ I Business Creation: Wall Street and Main Street \\ II Economic Change: Scope and Stability \\ III Business Creation and Economic Growth: Churning is Good \\ IV New Firms are the Major Source of New Jobs \\ V Different National Development, Different Processes \\ VI Context Counts, But May be Hard to Change

\section{Inside firm creation} \\ VII Growth Firms and Job Redistribution \\ VIII Money Necessary, But Not Sufficient \\ IX Everyone Pays, Some Benefit a Lot \\ X An Important Option for the Desperate

\section{Overview} \\ XI New Firms: Change Agents Hiding in Plain Sight
}

\section{NOTES}

1. Summary based on SEC Form 10-K filing (U.S. SEC, 2013) and public access summary of the firm history (Wikipedia, 2013). Facebook at https://en.wikipedia .org/w/index.php?title-Facebook\&oldid=78936914. Accessed 2013.

2 Summarized from Wikipedia (2020), McDonald's Corporation (2019) 10-K statement.

3. Wikipedia (2018b).

4. Greenhouse (2016).

5. U.S. Department of Labor, Bureau of Labor Statistics (2018).

6. Cramer and Krueger (2016).

Wikipedia (2018b).

8. Phrase made famous by Schumpeter (1934).

9. From Reynolds (2018, pg. 1); fictitious firm name.

10. From Reynolds (2018, pg. 15), fictitious names. 